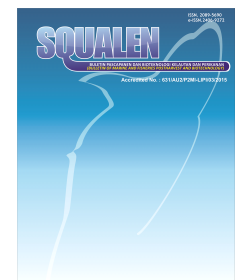

\title{
Identification of Protease-Producing Bacteria Isolated from Banyuwedang, Bali, and Characterization of its Protease
}

\author{
Dewi Seswita Zilda1*, Yusro Nuri Fawzya ${ }^{1}$ and Agustinus Robert Uria ${ }^{2}$ \\ ${ }^{1}$ Research and Development Center For Marine and Fisheries Product Processing and Biotecnology \\ Jalan KS Tubun Petamburan VI, Slipi, Jakarta Pusat 10260, Indonesia \\ ${ }^{2}$ Faculty of Pharmaceutical Sciences, Hokkaido University, Japan \\ Article history: \\ Received: 5 October 2018; Revised: 30 November 2018; Accepted: 18 December 2018
}

\begin{abstract}
Proteases or peptidases is known as a largest group of hydrolytic enzymes and have been applied in various industries such as food, pharmacy, leather, detergent and waste treatment. Although they are also produced by plants and animals, microbes remain the main source of proteases in the world market which mostly derived from Bacillus sp. Aims of this research were to identify isolate Bll-1 and study its protease. Analysis of 16Sr RNA sequencing showed the identity of Bll-1 as Bacillus subtilis ( $99 \%$ similarity with the same species in GenBank). It was found that protease from Bll-1 exhibited optimal temperature and $\mathrm{pH}$ of $50{ }^{\circ} \mathrm{C}$ and $8-9$, respectively. It was activated by $\mathrm{Li}^{2+}, \mathrm{Na}^{2+}, \mathrm{Mg}^{2+}$ and $\mathrm{K}^{+}$. The degenerated primer for protease gene was designed, and a partial protease gene was amplified from Bll-1. The sequencing result showed that this amplified gene shared 100 and $99 \%$ similarity with those from Geobacillus thermophiles and Bacillus subtilis in the GenBank, respectively.
\end{abstract}

Keywords: protease, bacteria, Bacillus subtilis, Geobacillus thermophylus

\section{Introduction}

Proteases are enzymes that catalyze proteolysis, which are classified as class 3 in enzyme classification. Based on their site of action, proteases are grouped into two majors, exopeptidases and endopeptidases. Proteases can be further classified based on catalytic sites as serine proteases, aspartic proteases, cysteine proteases and metalloproteases. Based on the optimal $\mathrm{pH}$ range of proteolytic activity, they are classified into acid, alkaline, and neutral proteases (Rao, M.B., Tanksale, A.M., Ghatge, M. S., \& Deshpande, V.V. 1998).

Proteases have been applied in various industrial processes such as degumming of silk, leather, pharmaceutical, food, detergent, processing of keratin residues, contact lens cleansing, biofilm removal, selective delignification of hemp, isolation of nucleic acid, photography and pest control (Kumar \& Bhalla, 2005; Pawar, R., Zambare, V., Barve, S., \& Paratkar,
G., 2009; Mahmoodi, N.M., Moghimi, F., Arami, M., \& Mazaheri, F., 2010; Giri et al., 2011; Harde, S.M., Bajaj, I.B., \& Singhal, R.S., 2011; Leslie, 2011; Joshi \& Satyanarayana, 2013; Khan, 2013; Motyan, J.A., Toth, F., \& Tozser, J., 2013; Kumar, D., \& Bhalla, T.C., 2015; Singh \& Bajaj, 2016; Suwannaphan, S., Fufeungsombut, E., Promboon, A., \& Chim-Anage, P., 2017). More recently proteases have been applied to produce high quality food supplement from hydrolyzed protein (Moreno et al., 2017).

Proteases found in the market is mostly produced by microorganisms although there are some produced by plants and animals. The total value of protease covers $60 \%$ of the total worldwide enzyme sales (Rani, K., Rana, R., \& Datt, S., 2012). This is because microbial properties exhibit advantageous properties that are useful for biotechnological processes such as their resilience under extreme temperature, $\mathrm{pH}$ and the presence of inhibitors (Singh \& Bajaj, 2017).

${ }^{*}$ Corresponding author.

E-mail: seswitazilda@gmail.com 
Hot spring become a promising source for discovering novel enzyme, especially thermostable enzyme as some proteases isolated from hot spring showed characteristics which meet industrial needs. Bacillus sp. isolated from hot springs in Limpopo Province, South Africa was reported producing 3 kinds of protease which can reduce phenol concentration. This is a substansial characteristic to be used for bioremediation (Jardine, J.L., Stoychev, S., Mavumengwana, V., \& Ubomba-Jaswa, E. 2018). Brevibacillus thermoruber OA30 produced protease 32-F38 which showed a great thermostability after $240 \mathrm{~min}$. It also showed a highly stable activity in the presence of different detergents and solvents (Gomri et al., 2018). An anaerobic thermophic bacteria had been isolated from a hydrothermal hot spring in Algeria, Caldicoprobacter algeriensis strain TH7C1, which showed capability of producing protease with high keratinolitic activity. The activity reach $21000 \mathrm{U} / \mathrm{ml}$ in just 24 hours of incubation at $50^{\circ} \mathrm{C}$. The properties of keratinases produced by this strain is promising to be applied for bioremediation and for the dehairing in the leather processing industry (Bouacem et al., 2016).

Indonesia is located on the ring of fire with countless of high temperature environments such as hydrothermal vent and hot springs which are yet to be explored. Exploration of microbial diversity to obtain novel proteases suitable for industrial processes is urgently needed. Aims of this research were to examine the properties of a protease produced by the bacterial isolate of BII-1 isolated from hot spring in Banyuwedang, Bali, identify the isolate and its partial protease gene.

\section{Materials and Methods}

\subsection{Microorganisms and Cultured Condition}

The protease-producing bacterial isolate BII-1 was isolated from Banyuwedang, Bali, and stored as a glycerol stock in $-80^{\circ} \mathrm{C}$. An aliquot of the glycerol stock was inoculated into a $150-\mathrm{ml}$ flask containing $50 \mathrm{ml} \mathrm{LB}$ medium. After $24 \mathrm{~h}$ of incubation at $37^{\circ} \mathrm{C}$, $10 \%$ of starter culture was transferred into a $500-\mathrm{ml}$ flask containing $150 \mathrm{ml}$ production medium $(0.1 \%$ of $\mathrm{K}_{2} \mathrm{HPO}_{4}, 0.1 \% \mathrm{NaCl}, 0.5 \%$ yeast extract, $0.01 \%$ $\mathrm{Mg}_{2} \mathrm{SO}_{4} \cdot 7 \mathrm{H}_{2} \mathrm{O}$ and $2 \%$ of skim milk). The cultivated microbial cells were harvested after 36 hours by centrifugation at $10.000 \mathrm{xg}$ for 10 minutes for being used in 16S rRNA analysis, and the resulting supernatant was used for enzyme characterization.

\subsection{DNA Extraction and 16S rRNA Identification}

Identification of protease-producing bacterium was conducted using 16S rRNA gene sequencing and
analysis.Genomic DNA was initially extracted using TIANamp Bacteria DNA Kit protocol. The extracted DNA was amplified using the universal 16S rRNA primers 27F-5'-AGAGTTTGATCCTGGCT CAG-3' and 1492R 5'-GGTTACCTTGTTACGACTT-3' (Lane, 1991). The sequence was subjected to a homology search against NCBI DNA database using BLAST Nn (Basic Local Alignment Search Toll) (Altscul, S.F., Gish, W., Miller, W., Myers, E.W., \& Lipman, D.J. 1990).) then aligned using Clustal W program (Higgins, D.G., Thompson, J.D., \& Gibson, T.J. (1996). The neighborjoining mid-point analysis (Kim, 1993) were performed using MEGA7 (Kumar, S., Stecher, G., \& Tamura, K. 2016).

\subsection{Partial Protease Gene Cloning}

Degenerated primer pair for amplifying partial protease genes (KerF 5'-TAYAYHGTNGGNTTYAAR3'; KerR 5' 5'NARNACYTTNACNCCRTA-3' /IDTIntegrated DNA Technologies) was designed and used to amplified a partial protease gene from the isolate BII - 1. The correct-sized PCR product (approximately $331 \mathrm{bp}$ ) was run on $1 \%$ agarose with $1 \mathrm{~kb}$ plus marker (Thermo Scientific). The appropriate size of band was purified using peqGOLD Gel Extraction Kit and sent for sequencing.

\subsection{Protease Assay}

Protease activity was determined by applying a modified method given by Takami, H., Akiba, T., \& Horikoshi, K. (1989). The mixture contained of $250 \mu \mathrm{L}$ of $1 \%$ casein (in Tris-Cl buffer pH of optimum enzyme) was incubated at optimum temperature with $250 \mu \mathrm{L}$ of protease sample for 10 minutes. The reaction was stopped by adding $500 \mu \mathrm{L}$ of $0.4 \mathrm{M}$ TCA. The mixture was centrifuged at $10.000 \times 9$ for 10 minutes. Supernatant $(500 \mu \mathrm{l})$ was mixed with $2500 \mu \mathrm{L}$ of 0.4 $\mathrm{M} \mathrm{Na}_{2} \mathrm{CO}_{3}$ and $250 \mu \mathrm{L}$ of Folin-Ciocalteu's Phenol Solution and incubated for 30 minutes at room temperature. The absorbance of the solutions were read against the sample blanks at $660 \mathrm{~nm}$ using Spectronic@20 GenesysTM. Tyrosine standard solution, in the range of $0-1000 \mathrm{mg} / \mathrm{L}$ was prepared in triplicates to obtain a standard curve. One unit $(U)$ of protease was defined as the amount of tyrosine $(\mu \mathrm{g} /$ $\mathrm{ml}$ ) in one minute under the defined assay conditions.

\subsection{Protease Characterization}

The protease activity at different $\mathrm{pHs}$, temperatures and metal ions was investigated. To determine the optimum temperature of enzyme activity, $250 \mu \mathrm{l}$ of enzyme was mixed with $250 \mu \mathrm{L}$ of $1 \%$ casein in TrisCl Buffer $\mathrm{pH} 9$ and incubated at different temperatures $\left(50-70^{\circ} \mathrm{C}\right)$ for 10 minutes and the reaction was 
terminated by adding $500 \mu \mathrm{L}$ of $0.4 \mathrm{M}$ trichloro acetic acid (TCA). Then the protease activity was measured as described earlier. The effect of different $\mathrm{pHs}$ on protease activity was determined by incubating 250 $\mu \mathrm{L}$ enzyme with $250 \mu \mathrm{L} 1 \%$ casein in $0.05 \mathrm{M}$ buffer of acetate (pH 5-6), phosphate (pH 6-8) and TrisCl $(\mathrm{pH}$ 8-10) for 10 minutes at $50^{\circ} \mathrm{C}$. The enzyme activity was terminated by adding $500 \mu \mathrm{L}$ of $0.4 \mathrm{M} \mathrm{TCA}$. Effect of various metal ions on enzyme activity was determined by incubating the enzyme with $1 \%$ of casein in appropriate buffer containing metal ions $\left(\mathrm{Co}^{2+}, \mathrm{Mg}^{2+}\right.$, $\mathrm{Li}^{2+}, \mathrm{Fe}^{2+}, \mathrm{Cu}^{2+}, \mathrm{Zn}^{2+} ; \mathrm{Mn}^{2+}$, and $\left.\mathrm{Ca}^{2+}\right)$ in the form of chloride $(\mathrm{Cl})$ salt at the final concentration of $5 \mathrm{mM}$ at $50^{\circ} \mathrm{C}$ for 10 minutes. The enzyme activity without metal ion was used as the negative control and was considered as $100 \%$ activity.

\section{Results and Discussion}

\subsection{S rRNA Identification}

Banyuwedang Bali is hot spring located in Desa Pejarakan, $140 \mathrm{~km}$ from Denpasar, Indonesia. The hot spring is in the center of mangrove forest with temperature of $44.8^{\circ} \mathrm{C}$ and $\mathrm{pH}$ of 8.1 . Some bacteria had been isolated from this site and kept as collection of Culture Collection laboratorium at Research and Development Center for Marine and Fisheries Product Processing and Biotechnology. One of those, BII-1, showed the capability to degrade skim milk by forming a large clear zone surrounding its colony (Figure 1). Its partial $16 \mathrm{~S}$ rRNA gene of 1465 bp showed $99 \%$ similar to Bacillus subtilis. (Figure 2).

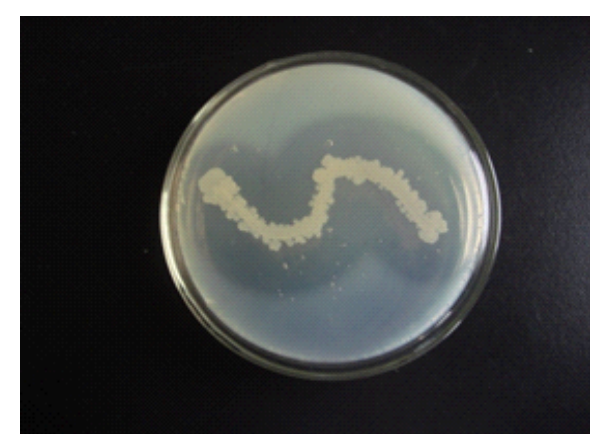

Figure 1. A clear zone formed by Bll-1 on solid MSM with $2 \%$ of skim milk

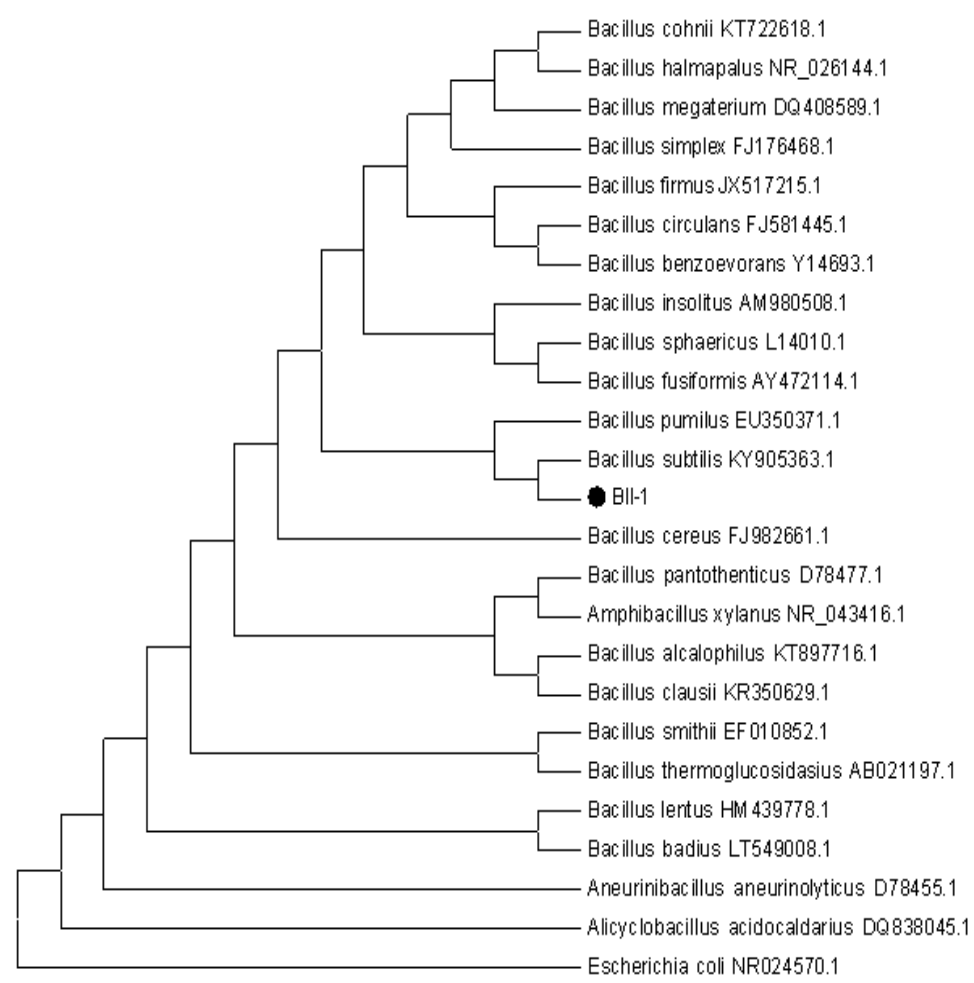

Figure 2. Neighbor-joining phylogenetic tree (bootsrap $=1000$ ) constructed by MEGA7 showing the relationship of BII-1 with members of Bacillus present in GenBank based on 16S rRNA gene analysis 


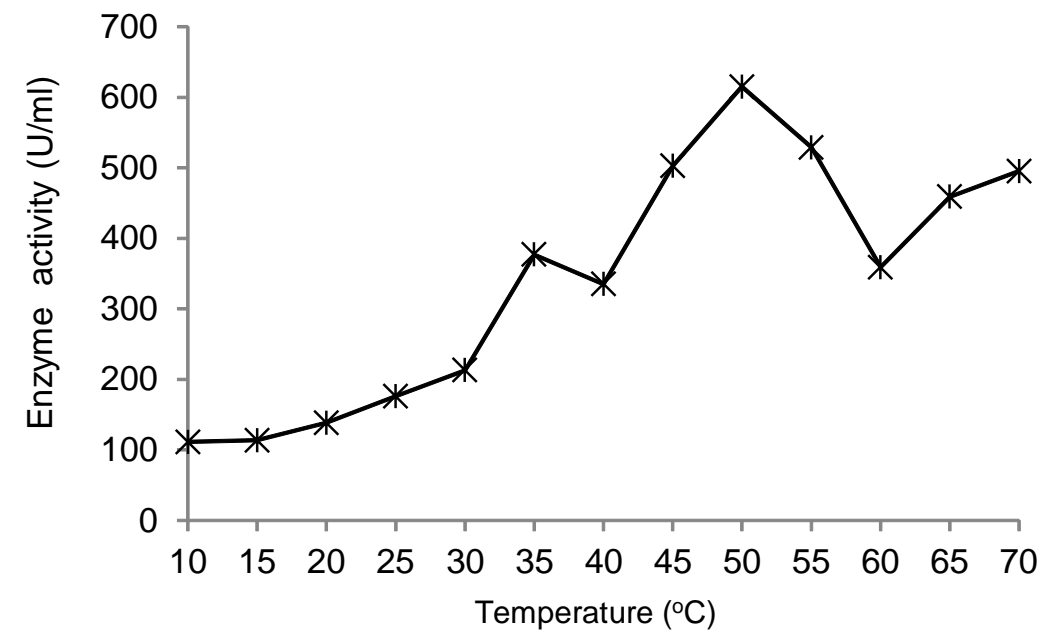

Figure 3. Protease Bll activity at various of temperatures. The assay was performed using $1 \%$ casein in 0.01 $\mathrm{mM}$ TrisCl buffer $\mathrm{pH} 9$

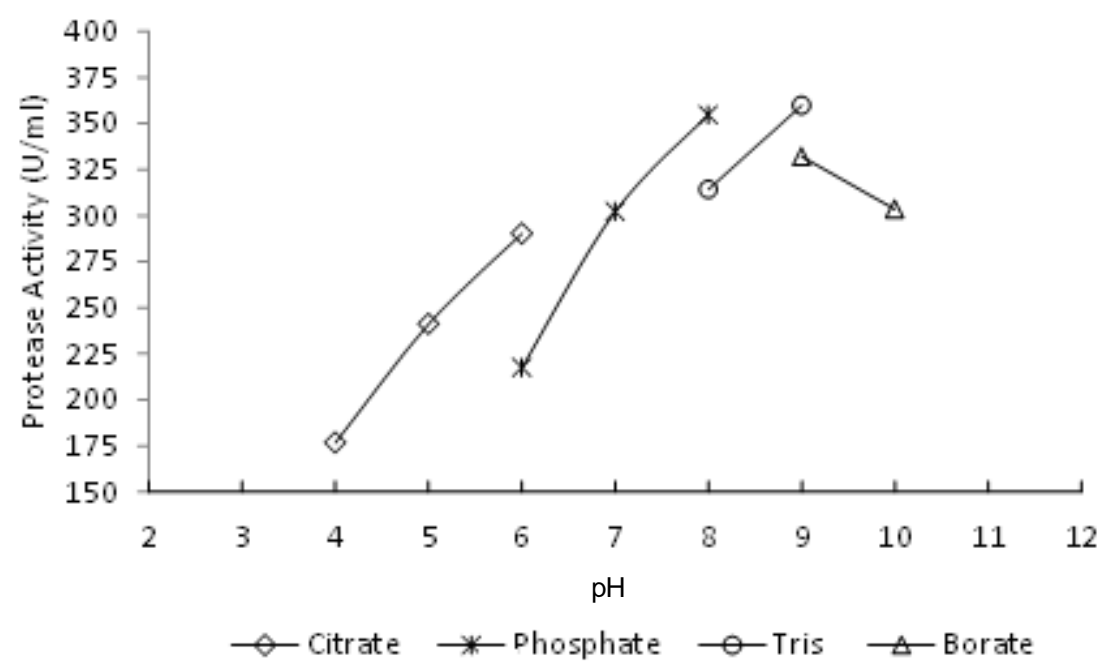

Figure 4. Activity of Bll-1 protease at various of $\mathrm{pHs}$. The assay was performed using $1 \%$ casein at $50^{\circ} \mathrm{C}$

Members of the genus Bacillus are important producers of proteases that account for $35 \%$ of the global market of industrially useful microbial enzymes (Jayakumar, R., Jayashree, S., Annapurna, B., \& Seshadri, S. 2012). Some preeminence characteristic of protease-producing Bacillus is their ability to produce enzymes that are suitable for industrial processes (Priya et al., 2014; Rehman et al., 2017), which are stable at extreme temperature, $\mathrm{pH}$ conditions, and the presence of solvents, detergents and other potential enzyme inhibitors (Joshi \& Satyanarayana 2013). Particularly, Bacillus subtilis, $B$. amyloliquefaciens, and $B$. licheniformis showed excellent fermentation properties with high product yields and lack of toxic byproducts (van Dijl, J., \& Hecker, M. 2013; Singh \& Bajaj, 2016; Guleria, S., Walia, A., Chauhan, A., \& Shirkot, C.K. 2016).

\subsection{The Properties of Protease}

Activity of the protease from BII-1 was investigated at different temperatures ranging from 10 to $70{ }^{\circ} \mathrm{C}$ using $1 \%$ casein as substrate. BII- 1 protease showed an optimum temperature at $50{ }^{\circ} \mathrm{C}$ (Figure 2). The activity significantly enhanced at $35^{\circ} \mathrm{C}$ and reached the highest at $50^{\circ} \mathrm{C}$. Most of thermostable proteases reported so far were produced by members of Bacillus (Anandharaj, M., Sivasankari, B., Siddharthan, N., Rani, R. P., \& Sivakumar, S. 2016); Singh \& Bajaj, 2017). Effect of temperature on the activity of BII-1 protease showed similar pattern with that produced by Bacillus tequilensis $\mathrm{P} 15$ with the optimum temperature of $50^{\circ} \mathrm{C}$ (Bose, A., Pathan, S., Pathak, K., \& Keharia, H. 2014). Bacillus pumilus MP 


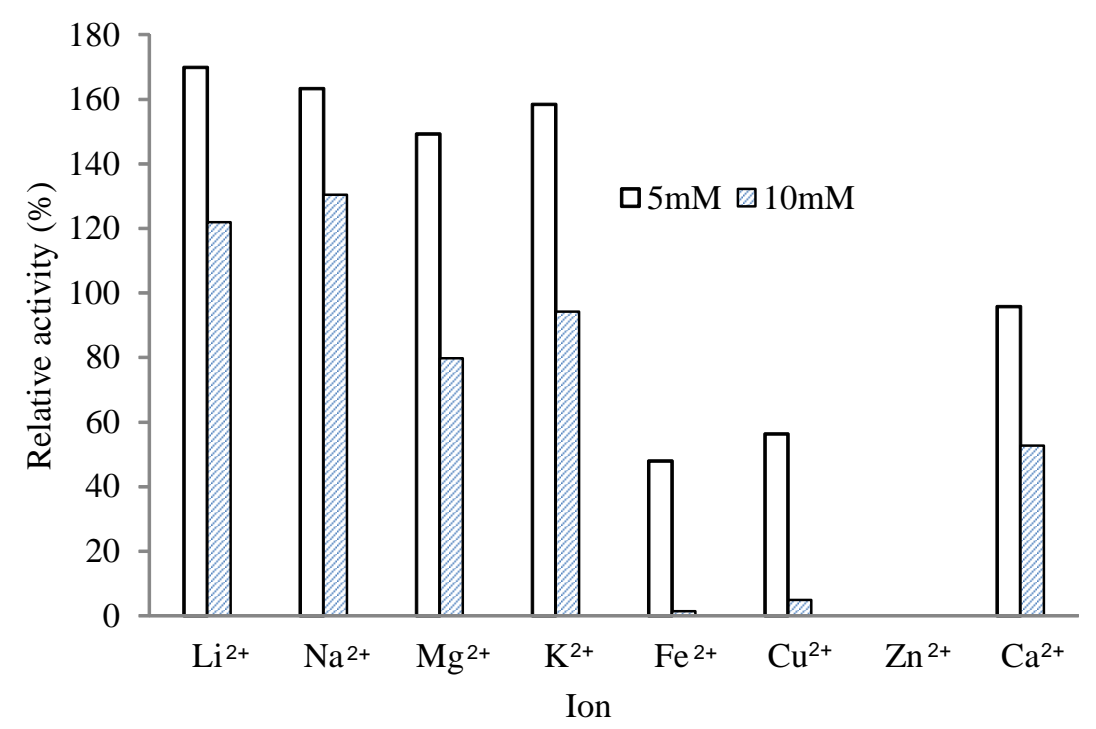

Figure 5. Activity of protease produced by BII-1 in the present of 5 and $1 \mathrm{mM}$ Metal ion. The activity of protease was measured at $50^{\circ} \mathrm{C}$ in Tris $-\mathrm{Cl}$ buffer $\mathrm{pH}$ of 9

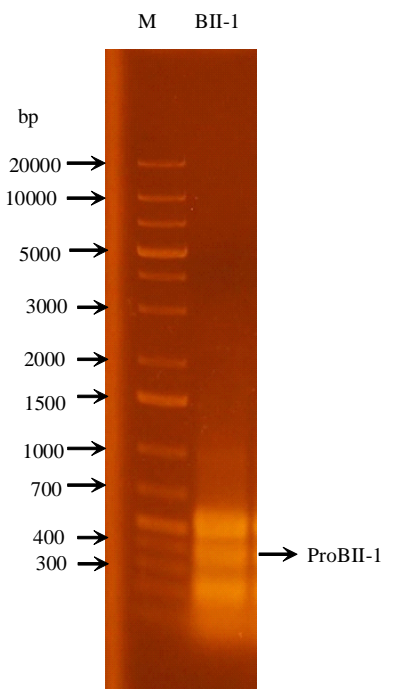

Figure 6 . ProBll-1 on $1 \%$ agarose. The size of protease band amplified with primer pair of KerF 5'-TAYAYHG TNGGNTTYAAR-3'; KerR 5' 5'NARNACYTTNACNCCRTA-3' is .350 bp (M=Marker)

27 isolated from sea water samples of Laut Selatan produced protease with the same optimum temperature (Baweja, M., Tiwari, R., Singh, P. K., Nain, L., \& Shukla, P. 2016). Marine Bacillus subtilis AP-MSU 6 produced protease with the highest activity at $40{ }^{\circ} \mathrm{C}$ (Maruthiah, T., Esakkiraj, P., Prabakaran, G., Palavesam, A., \& Immanuel, G. 2013) and B. subtilis GA CAS8 at $50{ }^{\circ} \mathrm{C}$ (Sathishkumar, R., Ananthan, G. \& Arun, J. 2015). It proved that the same species of microorganism could produce enzyme with different properties.

The effect of $\mathrm{pH}$ on the activity of Bll protease was investigated under various $\mathrm{pH}$ ranging from $4-10$. The protease produced by BII-1 showed high activity at the $\mathrm{pH}$ range of $5-10$ with the highest activity at $\mathrm{pH} 9$ in Tris buffer (Figure 3). The result showed that such buffer used for determining the optimum $\mathrm{pH}$ influencing the enzyme activity. As indicated in Figure 3, the enzyme activity was significantly different between phosphate and Tris buffer at the $\mathrm{pH}$ of 8 . Similar activity pattern was also observed for citrate and phosphate buffers at $\mathrm{pH}$ of 6 .

The activity of Protease BII-1 was activated by $\mathrm{Li}^{2+}$, $\mathrm{Na}^{2+}, \mathrm{Mg}^{2+}$ and $\mathrm{K}^{+}$and enhanced the activity by 70 , 60,45 and $55 \%$ repectively while $\mathrm{Fe}^{2+}$, $\mathrm{Cu} 2^{2+}$ and $\mathrm{Zn}^{2+}$ inhibited the enzyme activity (Figure 5). Most of 


\begin{tabular}{|c|c|}
\hline $\begin{array}{l}\text { Bll-1pro } \\
\text { GQJK2pro } \\
\text { GeoPro } \\
\text { BacPro }\end{array}$ & $\begin{array}{ll}\text { TTTCCAACAATATGGATGTTATTAACATGAGCCTTGGCGGACCTTCTGGTTCTACAGCGC } & 60 \\
\text { TTTCCAACAATATGGATGTTATTAACATGAGCCTTGGCGGACCTTCTGGTTCTACAGCGC } & 1079821 \\
\text { TTTCCAACAATATGGATGTTATTAACATGAGCCTTGGCGGACCTTCTGGTTCTACAGCGC } & 60 \\
\text { TTTCCAACAATATGGATGTTATTAACATGAGCCTTGGCGGACCTTCTGGTTCTACAGCGC } 721\end{array}$ \\
\hline $\begin{array}{l}\text { Bll-1pro } \\
\text { GQJK2pro } \\
\text { GeoPro } \\
\text { BacPro }\end{array}$ & $\begin{array}{l}\text { TGAAAACAGTCGTTGATAAAGCCGTTTCCAGCGGTATCGTCGTTGCTGCCGCTGCCGGAA } 120 \\
\text { TGAAAACAGTCGTTGATAAAGCCGTTTCCAGCGGTATCGTCGTTGCTGCCGCTGCCGGAA } 1079761 \\
\text { TGAAAACAGTCGTTGATAAAGCCGTTTCCAGCGGTATCGTCGTTGCTGCCGCTGCCGGAA } 1389 \\
\text { TGAAAACAGTCGTTGATAAAGCCGTTTCCAGCGGTATCGTCGTTGCTGCCGCTGCCGGAA } 781\end{array}$ \\
\hline $\begin{array}{l}\text { Bll-1pro } \\
\text { GQJK2pro } \\
\text { GeoPro } \\
\text { BacPro }\end{array}$ & $\begin{array}{l}\text { ACGAAGGTTCGTCCGGAAGCTCAAGCACAGTCGGCTACCCTGCAAAATATCCTTCTACTA } 180 \\
\text { ACGAAGGTTCGTCCGGAAGCTCAAGCACAGTCGGCTACCCTGCAAAATATCCTTCTACTA } 1079701 \\
\text { ACGAAGGTTCGTCCGGAAGCTCAAGCACAGTCGGCTACCCTGCAAAATATCCTTCTACTA } 1449 \\
\text { ACGAAGGTTCGTCCGGAAGCTCAAGCACAGTCGGCTACCCTGCAAAATATCCTTCCACTA } 841\end{array}$ \\
\hline $\begin{array}{l}\text { Bll-1pro } \\
\text { GQJK2pro } \\
\text { GeoPro } \\
\text { BacPro }\end{array}$ & $\begin{array}{l}\text { TTGCGGTAGGTGCGGTAAACAGCAGCAACCAAAGAGCTTCATTCTCAAGCGCAGGTTCTG } 240 \\
\text { TTGCGGTAGGTGCGGTAAACAGCAGCAACCAAAGAGCTTCATTCTCAAGCGCAGGTTCTG } 1079641 \\
\text { TTGCGGTAGGTGCGGTAAACAGCAGCAACCAAAGAGCTTCATTCTCAAGCGCAGGTTCTG } 1509 \\
\text { TTGCGGTAGGTGCGGTAAACAGCAGCAACCAAAGAGCTTCATTCTCAAGCGCAGGTTCTG } 901\end{array}$ \\
\hline $\begin{array}{l}\text { Bll-1pro } \\
\text { GQJK2pro } \\
\text { GeoPro } \\
\text { BacPro }\end{array}$ & $\begin{array}{l}\text { AGCTTGATGTGATGGCTCCTGGCGTATCCATCCAAAGCACACTTCCTGGAGGCACTTACG } 300 \\
\text { AGCTTGATGTGATGGCTCCTGGCGTATCCATCCAAAGCACACTTCCTGGAGGCACTTACG } 1079581 \\
\text { AGCTTGATGTGATGGCTCCTGGCGTATCCATCCAAAGCACACTTCCTGGAGGCACTTACG } 1569 \\
\text { AGCTTGATGTGATGGCTCCTGGCGTATCCATCCAAAGCACACTTCCTGGAGGCACTTACG } 961\end{array}$ \\
\hline $\begin{array}{l}\text { Bll-1pro } \\
\text { GQJK2pro } \\
\text { GeoPro } \\
\text { BacPro }\end{array}$ & $\begin{array}{l}\text { GTGCTTACAACGGCACGTCCATGGCATCTCC } 331 \\
\text { GTGCTTACAACGGCACGTCCATGGCGACTCC } 1079550 \\
\text { GTGCTTACAACGGCACGTCCATGGC } 1594 \\
\text { GTGCTTACAACGGCACGTCCATGGC } 986\end{array}$ \\
\hline
\end{tabular}

Figure 7. The sequence of ProBll-1 compared to protease gene of Bacillus subtilis GQJK2 (CP021498.1),

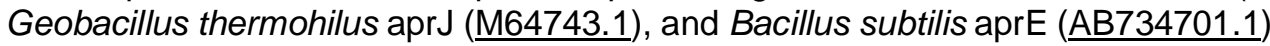

alkaline protease were activated by $\mathrm{Ca}^{2+}$. But protease Bll-1 was not influenced by $\mathrm{Ca}^{2+}$. Protease produced by Bacillus subtilis AP-MSU 6 showed different reaction to $\mathrm{Cu}^{2+}$ which enhance its activity (Maruthiah, T., Esakkiraj, P., Prabakaran, G., Palavesam, A., \& Immanuel, G. 2013) as well those produced by $V$. fluvialis TKU005 (Wang, S.L., Chio, Y.H., Yen, Y.H., \& Wang, C.L. 2007) and Thermoplasma volcanium (Kocabiyik \& Özel, 2007).

\subsection{Identification of BII Protease Gene}

A partial region of Bll protease (ProBll-1) was amplified with a pair of degenerated primers with the PCR product size of $331 \mathrm{bp}$ designated in this work (Figure 6). The result showed that ProBII-1 was $99 \%$ similar to that of Bacillus subtilis strain GQJK2 (CP021498.1), $100 \%$ of Geobacillus thermophilus aprJ (M64743.1) and $99 \%$ of Bacillus subtilis aprE (AB734701.1) (Figure 7.). It was previously reported by Jang et al (1992) that recombinant protease from $B$. subtilis GQJK2 showed $50 \%$ activity after being heated for 30 minutes at $60{ }^{\circ} \mathrm{C}$. The optimum temperature of heterologously expressed protease from $B$. subtilis aprE was approximally $50^{\circ} \mathrm{C}$ (Han et al., 2013).

\section{Conclusion}

Protease produced by bacterial isolate BII-1 was expected to be thermostable protease as it showed clear zone on solid medium that incubated at $55^{\circ} \mathrm{C}$. It refer to the fact that protease partial gene of BII-1 also showed similarity to two thermostable protease genes belong to Bacillus subtilis aprE and Geobacillus thermophylus aprJ which were reported as thermostable protease.

\section{Acknowledgement}

This work was financially supported by the Ministry of Marine Affairs and Fisheries, Republic of Indonesia (MMAF) granted to BBRP2BKP. The authors are grateful to Prof. Ekowati Chasanah for hot spring samples and Yudi Kusnadi and Seprianto for laboratory assistance.

\section{References}

Altscul, S.F., Gish, W., Miller, W., Myers, E.W., \& Lipman, D.J. (1990). Basic local alignment search tool. J. Mol. Biol. 215: 403-410.

Anandharaj, M., Sivasankari, B., Siddharthan, N., Rani, R. P., \& Sivakumar, S. (2016). Production, purification, and biochemical characterization of thermostable 
metallo-protease from novel Bacillus alkalitelluris TWI3 isolated from tannery waste. Applied bBiochemistry and bBiotechnology, 178(8), 16661686.

Baweja, M., Tiwari, R., Singh, P.K., Nain, L., \& Shukla, P. (2016). An Alkaline Protease from Bacillus pumilus MP1 27: Functional Analysis of Its Binding Model toward Its Applications As Detergent Additive. Front. Microbiol. 7:1195. doi: 10.3389/fmicb.2016.01195

Baweja, M., Tiwari, R., Singh, P. K., Nain, L., \& Shukla, P. (2016). An alkaline protease from Bacillus pumilus MP 27: functional analysis of its binding model toward its applications as detergent additive. Frontiers in mMicrobiology, 7, 1195.

Bose, A., Pathan, S., Pathak, K., \& Keharia, H. (2014). Keratinolytic protease production by Bacillus amyloliquefaciens $6 \mathrm{~B}$ using feather meal as substrate and application of feather hydrolysate as organic nitrogen input for agricultural soil. Waste and Biomass Valorization, 5(4), 595-605.

Bouacem, K., Bouanane-Darenfed, A., Jaouadi, N.Z., Joseph, M., Hacene, H., Ollivier, B., ...\& Jaouadi, B. (2016). Novel serine keratinase from Caldicoprobacter algeriensis exhibiting outstanding hide dehairing abilities. International Journal of Biological Macromolecules, 86, 321-328.

Giri, S.S., Sukumaran, S., Sen, S.S., Olive, M., Banu, N., \& Jena, P.K. (2011). Oxidizing agent stable alkaline protease from a newly isolated Bacillus subtiis VSG4 of tropical soil. J. Microbiol 49: 455-461

Gomri, M.A., Rico-Díaz, A., Escuder-Rodríguez, J.J., El. Moulouk Khaldi, T., González-Siso, M.I., \& Kharroub, K. (2018). Production and Characterization of an Extracellular Acid Protease from Thermophilic Brevibacillus sp. OA30 Isolated from an Algerian Hot Spring. Microorganisms, 6(2), 31.

Guleria, S., Walia, A., Chauhan, A., \& Shirkot, C. K. (2016). Purification and characterization of detergent stable alkaline protease from Bacillus amyloliquefaciens SP1 isolated from apple rhizosphere. Journal of Basic mMicrobiology, 56(2),138-152.

Han, X., Shiwa, Y., Itoh, M., Suzuki, T., Yoshikawa, H., Nakagawa, T., \& Nagano, H. (2013). Molecular Cloning and Sequence Analysis of an Extracellular Protease from Four Bacillus subtilis Strains. Bioscience, Biotechnology, and Biochemistry, 77(4), 870-873.

Harde, S.M., Bajaj, I.B., \& Singhal, R.S. (2011). Optimization of fermentative production of keratinase from Bacillus subtilis NCIM 2724. Agric. Food Anal. Bacteriol 1:54-65

Higgins, D.G., Thompson, J.D., \& Gibson, T.J. (1996). [22] Using CLUSTAL for multiple sequence alignments. In Methods in enzymology 266: 383-402. Academic Press.

Jang, J.S., Kang, D.O., Chun, M.J., \& Byun, S.M. (1992). Molecular cloning of a subtilisin $\mathrm{J}$ gene from Bacillus stearothermophilus and its expression in Bacillus subtilis. Biochemical and Biophysical Research Communications, 184(1), 277-282.
Jardine, J.L., Stoychev, S., Mavumengwana, V., \& Ubomba-Jaswa, E. (2018). Screening of potential bioremediation enzymes from hot spring bacteria using conventional plate assays and liquid chromatography-Tandem mass spectrometry (Lc-Ms/ Ms). Journal of Environmental Management, 223, 787-796.

Jayakumar, R., Jayashree, S., Annapurna, B., \& Seshadri, S. (2012). Characterization of thermostable serine alkaline protease from an alkaliphilic strain Bacillus pumilus MCAS8 and its applications. Applied Biochemistry and Biotechnology, 168(7), 1849-1866.

Joshi, S., \& Satyanarayana, T. (2013). Characteristics and applications of a recombinant alkaline serine protease from a novel bacterium Bacillus lehensis. Bioresour Technol 131:76-85

Khan, F. (2013). New microbial proteases in leather and detergent industries. Innov Res Chem 1:1-6

Kim, J. (1993). Improving the accuracy of phylogenetic estimation by combining different methods. Systematic Biology, 42(3), 331-340.

Kocabýyýk, S., \& Özel, H. (2007). An extracellularPepstatin insensitive acid protease produced by Thermoplasma technology, 98(1), 112-117.

Kumar, R.S, Rajesh, R., Gokulakrishnan, S., \& Subramanian, J. (2015). Screening and characterization of fibrinolytic protease producing Bacillus circulans from mangrove sediments Pitchavaram, South East Coast of India. Int Lett Nat Sci 1:10-16

Kumar, D., \& Bhalla, T.C. (2005). Microbial proteases in peptide synthesis: approaches and applications. Applied Microbiology and Biotechnology, 68(6), 726-736.

Kumar, S., Stecher, G., \& Tamura, K. (2016). MEGA7: molecular evolutionary genetics analysis version 7.0 for bigger datasets. Molecular Biology and Evolution, 33(7), 1870-1874.

Lane, D.J. (1991). Nucleic Acid Techniques in Bacterial Systematics. Stackebrandt, E., and Goodfellow, M. (eds). New York: Wiley, 115-175

Leslie, A. (2011). Preventing biofilm formation using microbes and their enzymes. Basic Biotechnol 7:611

Ma, J., Liu, H., Wang, C., Xia, Z., Liu, K., Hou, Q., Li, Y., Zhang, T., Wang, H., Wang, B., Wang, Y., Ge, R., Xu B, Yao, G., Jiang, Z., Hou, W., Ding, Y., \& Du, B. (2017). Complete genome sequence of Bacillus subtilis GQJK2, a plant growth-promoting rhizobacterium with antifungal activity. Genome Announc 5:e00467-17.

Mahmoodi, N.M,, Moghimi, F., Arami, M., \& Mazaheri, F. (2010). Silk degumming using microwave irradiation as an environmentally friendly surface modification method. Fiber Polym 11:234-240

Maruthiah, T., Esakkiraj, P., Prabakaran, G., Palavesam, A., \& Immanuel, G. (2013). Purification and 
characterization of moderately halophilic alkaline serine protease from marine Bacillus subtilis AP-MSU 6. Biocatalysis and Agricultural Biotechnology, 2(2), 116-119.

Moreno PJG, Pérez, G.R, Espejo, C.F.J., Ruiz-Quesada, C., Pérez-Morilla, A., Martínez-Agustín O., ...... Guadix, E.M. (2017). Functional, bioactive and antigenicity properties of blue whiting protein hydrolysates: effect of enzymatic treatment and degree of hydrolysis. J. Sci. Food \& Agri.97, 299-308.

Motyan, J.A., Toth, F., \& Tozser, J. (2013). Research applications of proteolytic enzymes in molecular biology. Biomolecules 3:923-942

Pawar, R., Zambare, V., Barve, S., \& Paratkar, G. (2009). Application of protease isolated from Bacillus sp. 158 in enzymatic cleansing of contact lenses. Biotechnology 8:276-280

Priya, J.D.A., Divakar, K., Prabha, M. S., Selvam, G. P., \& Gautam, P. (2014). Isolation, purification and characterisation of an organic solvent-tolerant $\mathrm{Ca} 2+-$ dependent protease from Bacillus megaterium AU02. Applied biochemistry and biotechnology, 172(2), 910-932.

Rao, M.B., Tanksale, A. M., Ghatge, M. S., \& Deshpande, V. V. (1998). Molecular and biotechnological aspects of microbial proteases. Microbiology and molecular biology reviews, 62(3), 597-635.

Rani, K., Rana, R., \& Datt, S. (2012) Review on latest overview of proteases. Int J Curr Life Sci 2:12-18

Rehman, R., Ahmed, M., Siddique, A., Hasan, F., Hameed, A., \& Jamal, A. (2017). Catalytic role of thermostable metalloproteases from Bacillus subtilis KT004404 as dehairing and destaining agent. Applied Biochemistry and Biotechnology, 181(1), 434-450.
Sathishkumar, R., Ananthan, G., \& Arun, J. (2015). Production, purification and characterization of alkaline protease by ascidian associated Bacillus subtilis GA CAS8 using agricultural wastes. Biocatalysis and Agricultural Biotechnology, 4(2), 214-220.

Singh, S., \& Bajaj B.K. (2016). Bioprocess optimization for production of thermoalkali-stable protease from Bacillus subtilis $\mathrm{K}-1$ under solid-state fermentation, Preparative Biochem \& Biotech, 46:7, 717-724

Singh, S., \& Bajaj B.K. (2017) Agroindustrial/forestry residues as substrates for production of thermoactive alkaline protease from Bacillus licheniformis K-3 having multifaceted hydrolytic potential. Waste Biomass Valoriz 8:453-462

Suwannaphan, S., Fufeungsombut, E., Promboon, A., \& Chim-Anage, P. (2017). A serine protease from newly isolated Bacillus sp. for efficient silk degumming, sericin degrading and colour bleaching activities. International Biodeterioration \& Biodegradation, 117, 141-149.

Takami, H., Akiba, T., \& Horikoshi, K. (1989). Production of extremely thermostable alkaline protease from Bacillus sp. no. AH-101. Applied Microbiology and Biotechnology, 30(2), 120-124.

van Dijl, J., \& Hecker, M. (2013). Bacillus subtilis: from soil bacterium to super-secreting cell factory. Microbial Cell Factories. 12:3

Wang, S.L., Chio, Y.H., Yen, Y.H., \& Wang, C.L. (2007). Two novel surfactant-stable alkaline proteases from Vibrio fluvialis TKU005 and their applications. Enzyme and microbial technology, 40(5), 1213-1220. 